\section{Are Thrombotic Events in Antineutrophil Cytoplasmic Antibody-associated Vasculitis Related to the Effect of Antiphospholipid Antibodies?}

\section{To the Editor:}

The high incidence of thrombotic phenomenon among individuals with antineutrophil cytoplasmic antibody-associated vasculitis (AAV) was the subject of an intriguing article by Kang, et $a l^{1}$. The reported susceptibility to both arterial and venous thrombotic events is also uniquely characteristic of the antiphospholipid syndrome ${ }^{2,3}$. Similarly, a possible explanation for thrombotic events in AAV may be modulation of platelet function by antiphospholipid antibodies (aPL) ${ }^{4}$. Given the similarities between the 2 phenomena, it would seem reasonable to assess presence of aPL, at least in AAV patients with thrombotic events, if not in all individuals with AAV, and to act prophylactically in the latter group. This is especially pertinent for those with thrombotic events, because presence of aPL requires modification of standard intervention ${ }^{5}$. Which antibodies to test for? I suggest $\operatorname{IgG}, \operatorname{IgM}$, and $\operatorname{IgA}$ antibodies to anticardiolipin, $\beta_{2}$-glycoprotein I, and antiphosphatidylserine/prothrombin ${ }^{6}$.

If aPL are present, use of aspirin or a cyclooxygenase 1-predominant nonsteroidal antiinflammatory drug (NSAID) might be considered. While use of low-dose aspirin for primary prevention of antiphospholipid complications has been a matter for debate ${ }^{7}$, there is an explanation for the confusion. It arises from the assumption that standard aspirin dosing $(<100$ $\mathrm{mg} /$ day) is a valid approach. There is significant variation in aspirin's clinical efficacy as an inhibitor of platelet function. As high a dose as $1000 \mathrm{mg}$ per day may be required and even that may not be effective. Simply prescribing aspirin or an NSAID, without assessing efficacy as an inhibitor of platelet function and compliance, is inadequate. Platelet function testing (of response to epinephrine and collagen) is essential. Failure to produce response time prolongation (interference with platelet function) identifies inadequate efficacy $^{8}$. If anticoagulation intervention is alternatively chosen, the options are unfractionated heparin or high-dose warfarin (3.0-3.5 international normalized ratio $)^{5}$. Unfortunately, the very convenient fractionated heparins have been ineffective in preventing further thrombotic events in individuals with antiphospholipid syndrome $e^{9,10}$.

BRUCE M. ROTHSCHILD 10 , MD, Indiana University School of Medicine, Muncie, Indiana, USA. Address correspondence to Dr. B.M. Rothschild, 2401 W. University Ave., Muncie, Indiana 47303, USA. E-mail: spondylair@gmail.com

\section{REFERENCES}

1. Kang A, Antonelou M, Wong NL, Tanna A, Arulkumaran N, Tam FW, et al. High incidence of arterial and venous thrombosis in antineutrophilic cytoplasmic antibody-associated vasculitis. J Rheumatol 2019:46;285-93.

2. Garcia D, Erkan D. Diagnosis and management of the antiphospholipid syndrome. N Engl J Med 2018;378:2010-21.

3. Yalavarthi S, Gould TJ, Rao AN, Mazza LF, Morris AE, Núñez-Alvarez C, et al. Release of neutrophil extracellular traps by neutrophils stimulated with antiphospholipid antibodies: a newly identified mechanism of thrombosis in the antiphospholipid syndrome. Arthritis Rheum 2015;67:2990-3003.

4. Cohen D, Berger SP, Steup-Beekman GM, Bloemenkamp KW, Bajema IM. Diagnosis and management of the antiphospholipid syndrome. BMJ 2010;340:2541.

5. Khamashta MA, Cuadrado MJ, Mujic F, Taub NA, Hunt BJ, Hughes GR. The management of thrombosis in the antiphospholipid-antibody syndrome. N Engl J Med 1995; 332:993-7.

6. Bertolaccini ML, Amengual O, Atsumi T, Binder WL, deLaat B, Forestiero R. "Non-criteria" aPL tests: Report of a task force and preconference workshop at the 13th International Congress on antiphospholipid antibodies, Galveston, TX, USA, April 2010 Lupus 2011;20:191-205.

7. Arnaud L, Mathian A, Ruffatti A, Erkan D, Tektonidou M, Cervera $\mathrm{R}$, et al. Efficacy of aspirin for the primary prevention of thrombosis in patients with antiphospholipid antibodies: an international and collaborative meta-analysis. Autoimmun Rev 2014;13:281-91.

8. Rothschild BM. Comparative anti-platelet activity of COX-1 NSAIDS versus aspirin, encompassing regimen simplification and gastroprotection: a call for a controlled study. Reumatismo 2004;56:89-93.

9. Meroni PL, Chighizola CB, Gerosa M, Trespidi L, Acaia B. Obstetric antiphospholipid syndrome: lobsters only? Or should we also look for selected red herrings? J Rheumatol 2015;42:158-60.

10. Ziakas PD, Pavlou M, Voulgarelis M. Heparin treatment in antiphospholipid syndrome with recurrent pregnancy loss: a systematic review and meta-analysis. Obstet Gynecol 2010;115:1256-62.

First Release June 1 2019; J Rheumatol 2019;46:7; doi:10.3899/jrheum.190358 